\title{
A Sport for Gentle Bloods
}

\section{Bruce Boehrer}

\section{(2) OpenEdition \\ Journals}

Electronic version

URL: http://journals.openedition.org/shakespeare/5372

DOI: $10.4000 /$ shakespeare. 5372

ISSN: 2271-6424

\section{Publisher}

Société Française Shakespeare

\section{Electronic reference}

Bruce Boehrer, «A Sport for Gentle Bloods », Actes des congrès de la Société française Shakespeare [Online], 38 | 2020, Online since 25 June 2020, connection on 06 July 2020. URL : http://

journals.openedition.org/shakespeare/5372; DOI : https://doi.org/10.4000/shakespeare.5372

This text was automatically generated on 6 July 2020.

(c) SFS 


\title{
A Sport for Gentle Bloods
}

\author{
Bruce Boehrer
}

1 While early modern hunting treatises remain an obscure field of study, George Gascoigne's Noble Arte of Venerie (1575) has received unusual notice of late, largely because of four poems inserted into the text of the work and composed in the voice of four different game animals: the hart, hare, otter, and fox. ${ }^{1}$ These poems-complaints against the wanton cruelty of human hunters, directed against them by the objects of their savagery-seem to "challenge ... the presumptions of 'master man"' by offering "a counter-cultural discourse and ... an alternative mode of subjectivity, one as far removed as possible from that of the masterly male." ${ }^{2}$ This view of the work appeals to readers seeking evidence of growth, during the early modern period, in sympathetic identification with the natural world: the development traced broadly by Keith Thomas's Man and the Natural World and arguably reflected in humanist denunciations of the hunt. For Shakespeareans, more particularly, Gascoigne's work, with its compassion for the suffering of game-animals, seems to anticipate the "conservationist strain" of As You Like It (1598-9), a play that likewise seems to echo the opposition to hunting voiced by sixteenth-century humanists. ${ }^{3}$ However, the theriophily of writers like Gascoigne and Shakespeare needs to be understood less as a prescription for ethical behavior than as evidence of a guilty conscience: a recognition of humanity's interests-a recognition, in effect, of fallen human nature-as irredeemably injurious to the rest of creation.

2 In what follows I revisit the relationship between Gascoigne and Shakespeare, most particularly with respect to their treatment of non-human species but more generally with regard to their treatment of what we would now call ecological issues. In this process, non-human animals come to stand in for the natural world more broadly, and our ultimate object of consideration will be humanity's violent and exploitative environmental tendencies, as these are metonymically configured in cross-species relations. Even in the sixteenth century, hunting elicited emphatic and divergent responses, many celebrating the chase as fervently as some few chose to condemn it; unusually, however, one encounters the full range of these responses both in Gascoigne's Noble Arte and in As You Like It. Since there exists a clear if indirect line of influence between Shakespeare's comedy and Gascoigne's work more generally, As You 
Like It and The Noble Arte beg for side-by-side reappraisal, with particular focus on how they integrate their theriophile sentiments into the more normatively speciesist cultural environment for which they were designed.

3 There are three problems with the view that Gascoigne's work "ask[s] his readers to show some compassion towards the animals they hunted, killed and consumed." ${ }^{4}$ First, his animal poems lie buried in a lavish 250-page hunting manual Gascoigne painstakingly translated from the French and adapted for the English market, a manual whose purpose runs directly counter to the compassionate sentiments of his animalpoems. Second, Gascoigne's animal-poems themselves build upon precedent established in the work he translates, one of those poems ("The wofull words of the Hart to the Hunter") already appearing in the original text reworked by Gascoigne, Jacques du Fouilloux's La vénerie (1561), where a 98-line "Complaint du cerf" inserted by Fouilloux's original editor, Guillaume Bouchet, condemns the cruelty of hunters. ${ }^{5}$ And finally, Gascoigne's and Bouchet's poems participate in an ancient and well-defined sub-genre of complaint verse, within whose boundaries they function less as dedicated moral or political discourse than as a disinterested rhetorical exercise. This is not to deny that Gascoigne's poems recognize the harm inflicted by hunters on game animals. However, the poems motivate this recognition not toward serious ethical engagement but rather toward complaisant dismissal. They stand in for more genuine acts of sympathy, deflecting these into the aesthetic realm and stripping them, in the process, of any practical consequence.

4 As for the real practical application of Gascoigne's poems, this seems focused largely on the medicinal properties extracted from their respective beasts. The fox boasts, for instance, that

His Lungs full holsome be, In pouder beaten fine,

For such as cough \& draw their wind, With paine and mickle pine.

His pissell serues to scoure,

The grauell of the stone,

His greace is good for sinews shronke,

Or ache that grieues the bone. ${ }^{6}$

5 The hart likewise describes the medicinal virtues of his horns; then imagines how his "Sewet" might serve as liniment for "numme" joints; and adds two different and rather incompatible references to the legendary curative bezoar stone: one in which it forms out of the hart's "teares congeald to gumme," and another that locates it as a stone in his maw. ${ }^{7}$ A poem that denounces the "murdering cruell mind" of hunters while also extolling the curative properties of the game-animal's body-parts cannot expect its compassionate sentiments to be taken very seriously. ${ }^{8}$

6 In the case of Gascoigne's "Wofull words of the Hart to the Hunter," both the compassionate sentiments and the list of curatives come from Gascoigne's source, Bouchet's "Complaint du cerf," which likewise extols the medical virtues of deer-horn, deer-fat, and the bezoar-stone-this last again being traced inconsistently to the same two sources in deer-tears and the contents of the deer's stomach. Gascoigne's "Wofull words" expand upon Bouchet's poem by an additional thirty-six lines, ${ }^{9}$ but this expansion adds little to the poem's content, being mostly accounted for by otiose translation. (Bouchet's opening ten lines, for instance, become twenty in Gascoigne.) Indeed Bouchet's verse provides key elements for Gascoigne's animal-poems: 
inveighing against the cruelty of hunters, accusing them of inhumanity, and yet paradoxically commending the medical products afforded by the game-animal in question. And in Gascoigne, as in Bouchet, this contradiction is uncomfortably reconciled by shifting from animal to human perspective. Bouchet's hart makes a point of praising remedies extracted from his tears, cast horns, and fur without bloodshed; only later does he imagine a hunter dismembering him for his marrow and fat and the stones in his stomach. ${ }^{10}$ Likewise, Gascoigne's fox envisions human medical needs as one more incentive for his destruction, one more way to transform him into an object:

His tong will draw a thorne,

His teeth will burnish gold,

And by his death a huntsman may,

Haue profits manifold. ${ }^{11}$

7 These poems do indeed lament the suffering of hunted animals, but for both Bouchet and Gascoigne the lament itself goes out of its way-self-consciously so-to advertise the animals' usefulness in death.

8 This is the case because, following Bouchet, Gascoigne approaches his animal-poems as exercises in rhetoric rather than logic. Generically, these poems situate themselves in the realm of the verse complaint, a literary mode at its zenith in the late medieval and early modern periods. Given to histrionics and unusual situations, the complaint could draw on classical antecedents in Ovid's poems of exile, and by the sixteenth century, the form had expanded from conventional laments for lost love and the miscarriage of fortune to engage topics such as the poet's impecuniousness (Chaucer's "Complaint to his Purse") and the tragic mortality of butterflies (Spenser's "Muiopotmos"). One related lament, inspired by Ovid's mock-elegy for his mistress Corinna's parrot in Amores 2.6, comes from Jean Lemaire de Belges, the first of whose two Epitres de l'Amant Vert (1502) extravagantly mourns the self-inflicted demise of Margaret of Austria's pet parrot; another, Ronsard's "Contre les bûcherons de la forêt de Gastine" (1578), inveighs against the deforestation of woodlands in Touraine by the Duc de Vendôme. Bouchet's and Gascoigne's beast-complaints locate themselves in much the same literary terrain: just as Ronsard's "Contre les bûcherons" deplores the loss of trees without actually urging any action to stop it, these slightly earlier poems wring their hands over human misbehavior while taking such behavior for granted. This is much the posture one would expect from a poetic mode "rooted in the presumption of man's [sic] fallen state" and devoted to "the moral corruption of human nature."12

Indeed, Gascoigne's beast-poems nicely illustrate the tendency to deploy complaint "as decorative punctuation within a narrative considered ... to be of primary importance." ${ }^{13}$ Inserted at the end of those sections of The Noble Arte of Venerie dealing with their respective game-animals, the poems serve quite clearly as punctuation, their status as verse also producing a decorative effect amidst the surrounding prose. As decoration, they focus attention on the mediating presence of Gascoigne as he renders into English a work, du Fouilloux's La vénerie, that was itself a cento of earlier sources-most notably the Livre de chasse (1387-89) of Gaston Fébus, Comte de Foix. For Gascoigne, advertising the translator/editor's work becomes a natural priority: after all, The Noble Arte of Venerie is among other things an appeal for patronage. The treatise was accompanied, in its original 1575 edition, by a series of woodcuts of Queen Elizabeth presiding over the hunt (in the second edition, of 1611, King James is inserted in her place). The work's subject-matter connects, as Catherine Bates has noted, to the sylvan entertainments Gascoigne composed to honor the queen during her famous 1575 progress-visit to the 
Earl of Leicester's estate at Kenilworth, works which "sue for favour and offer [the queen] eternal service and obedience in return." ${ }^{14}$ And Edward Berry has observed that in the Noble Arte, "the dominance of the Queen herself is overwhelming," for "[i]n no other activity-political, religious, or social-was the Queen's authority so absolute as in the hunt." ${ }^{15}$ The role of translator/editor, in fact, seems uniquely appropriate for a courtier seeking patronage. By nature it involves a subordination of the self to prior authority-that of the text and author(s) being rendered-that parallels the subordination of self to patron. But if it is to lead to courtly advancement, the subordination in question must be rigorously distinguished from self-effacement.

10 Gascoigne's efforts, thus, draw attention to his interventions in and modifications of his received French text. In apparent deference to Queen Elizabeth's virginity, he suppresses a lengthy pastoral-erotic poem, "L'Adolescence de Jacques du Fouilloux," that appears in his source. ${ }^{16}$ In the process, he insists, "I haue dealt faithfully for so much as I translated, neither taking any thing from him [du Fouilloux], nor adding any thing but that which I haue plainly expressed"; as for du Fouilloux's "Adolescence," it is "more apt for lasciuious minds, than to be enterlaced amongst the noble termes of Venery." ${ }^{17}$ At another point, where du Fouilloux describes a typical hunters' breakfast sur l'herbe, complete with "some woman of repute" ("quelque femme de reputation") who enlivens the assembly with her "capers and the movement of her hips" ("ses passages et remuements de fesses"), Gascoigne replaces the full passage with a twopage description, in poulter's-measure couplets, of a similar gathering minus the dancer. ${ }^{18}$ Gascoigne's motto-"Tam Marti quam Mercurio"-holds a prominent place in The Noble Arte, appearing at bottom of the volume's first section of text, Gascoigne's verse preface "[I]n the commendation of the noble Arte of Venerie." And rightly so: The Noble Arte offers an exemplary exercise in the coordination of martial and literary disciplines-what the Japanese call "harmony of pen and sword." As such, it touts the dual expertise of its translator/editor while promoting his ambitions on both fronts. In such a context, the sufferings of the hunted cannot constitute a legitimate object of moral concern; they simply illustrate the sophistication of the hunter's brutality.

11 In fact, the commendatory verses that preface Gascoigne's translation offer a plain statement of the book's actual purpose. In them, Gascoigne makes much of the human need for entertainment as relief from the burden of living. "Contention comes by coyne," we are told, and "Man is born to dye"; that being so, the poet asks rhetorically, "Why lead not men such lives, in quiet comely wise,/ As might with honest sport and game, their worldly minds suffice"? ${ }^{19}$ The pursuit of game, Gascoigne continues, "Doth seeme to yeild as much content, as may on earth be sought," and its benefits, while extending to the health of the body, remain principally mental, helping "To recreate the minds of Men, in good and godly sort," occupying "the mind, which else might chance to muse/ On mischief, malice, filth, and fraudes." These sentiments run directly counter to the currently-popular view that Gascoigne condemns "the ethics of killing animals for pleasure" and particularly "the ruling elite, who butchered animals for pleasure and denied the common people the right to hunt for food." ${ }^{20}$ Nor should this surprise anyone: Gascoigne's translation addresses itself not to "the common people"-however that group might be understood-but to the gentry for whom hunting constituted a sign and attribute of rank. Thus for Gascoigne the chase remains first and last "A sport for Noble Peeres, a sport for gentle bloods," with "gentle" construed here in the old 
armigerous sense, only distantly related to modern usage of the word as "free from violence or severity." ${ }^{21}$

12 Indeed, Gascoigne's usage illustrates how far our modern understanding of gentleness has strayed from the word's original sense, bound up as this latter is in warrior identity and its rank-specific monopoly on violence. Thanks largely to the early modern period's gradual redefinition of the ruling elite as a leisure class rather than a warrior class, gentility has metamorphosed into gentleness, with the concomitant expectation that elite behavior will abandon brutishness for refinement and bloodshed for courtesy. However, the language of Gascoigne's work illustrates how little it participates in this latter-day ideal. Catherine Bates has rightly connected Gascoigne's beast-poems to "the enlightened humanist position-as expressed by the likes of Erasmus, More, and Agrippa-that deplored human violence in all its forms." ${ }^{22}$ But the connection needs to be understood less as discipleship than as co-optation. Here Edward Berry leads the way, suggesting that "[w]hat seems to be sensitivity to animal suffering . . . may actually be satiric contempt for the human condition." ${ }^{23}$ It is in this spirit that The Noble Arte of Venerie should be read alongside Shakespeare's As You Like It (1598-9), as a corrective to that play's annoying optimism.

13 Juliet Dusinberre has observed of Shakespeare's sunniest comedy that, despite its obvious debt to earlier pastoral drama, "its closest kinship is with the outdoor entertainments mounted for Elizabeth during her summer progresses." ${ }^{24}$ Since George Gascoigne served as a main deviser of these entertainments, there exists a direct channel of influence and affinity from his work to As You Like It, a connection perhaps best illustrated on the levels of character and setting. As Dusinberre points out, the "wretched ragged" (4.3.106) appearance of Oliver in Act 4 of Shakespeare's comedy restages the persona adopted by Gascoigne in his Kenilworth performances, while the hermits and magicians who populate the Forest of Arden recall similar figures from the progresses. The Golden Age environment of Arden, in turn, echoes the ideal world of Elizabethan courtly entertainment. So it should not surprise that the subject-matter of Gascoigne's animal-poems in The Noble Arte of Venerie likewise reappears in As You Like $I t$, in the form of Jaques' proto-animal-rights denunciation of hunting.

14 As to plot, As You Like It shares with Gascoigne's entertainments a reliance on spectacle rather than story, a reliance that leads Shakespeare's play to function less as a coherent narrative than as a series of tableaux vivants. The play's main action-reconciling brothers, marrying lovers-happens almost as an afterthought, with most of the business onstage devoted instead to a satirical exploration of manners: the pretensions of courtiership, the exaggerations of courtly love, the affectations of pastoral, the inherent snobbery of invidious distinctions between country and court. Played out against a backdrop of uncivilized green space, the artificiality of such behavior is thrown into relief, and the play's comedy proceeds through static expositions of the foibles associated with fashionable modes of self-construction. In this respect, As You Like It also displays marked similarity to the other plays associated with the late Elizabethan War of the Theaters; Ben Jonson's Every Man Out of His Humor (1599), Cynthia's Revels (1600), and Poetaster (1601), for instance, notably subordinate plot to repartee..$^{25}$

15 In its core affiliations, As You Like It thus finds itself torn between an idea of utopiathe contented world of pastoral presupposed by Queen Elizabeth's entertainments-and an idea of social critique-the disparaging commentary on customs and attitudes 
typical of late Elizabethan satirical comedy. The former connection displays itself most clearly in the play's caramelized depictions of life in the green world-that "sweet" space, "free from peril," where "the penalty of Adam" goes miraculously unfelt (2.1.2, 4-5)-and in the play's concluding wedding-masque (5.4.108-44). The latter, satirical connection most appears when the play critiques fashionable behavior, as when Rosalind punctures the conventions of courtly love ("Men have died from time to time, and worms have eaten them, but nor for love" [4.1.106-8]) or mocks Jaques' voguish melancholy ("I had rather have a fool to make me merry than experience to make me sad" [4.1.21-2]). When the play treats of hunting, its discourse again develops relative to these two literary modes. On one hand, As You Like It participates in an "aristocratic 'pastoralizing' of the hunt" also visible in Sir Philip Sidney's Arcadia, a process of accommodating the chase to the ethic of pastoral by redefining it as a subsistence activity, conducted not for sport or for military training, but for the procurement of food. ${ }^{26}$ On the other hand, the humanist critique of hunting-thanks to More and Erasmus long associated with satire-emerges in Duke Senior's concern for the welfare of Arden's deer and more pointedly in the expanded form of this concern attributed to Jaques. In the process, the play attempts to assimilate hunting to a vision of pastoral utopia while nonetheless seeking to hold at bay the sense that any such assimilation is futile.

16 Indeed, given As You Like It's insistent optimism, one can only marvel at how much the play concerns itself with the core sources of division and discontent in Elizabethan society's relations with the green world. The play is haunted by questions of access to green space and the resources it harbors. Fleeing their wonted abode for the shelter of the forest, Duke Senior and his followers reenact on the aristocratic level "the resistance of woodland commoners and squatters to enclosure." ${ }^{27}$ The "churlish" (2.4.80) landowner from whom Rosalind and Celia purchase their woodland cottage embodies the injustices associated with absentee landlordism. The threat of starvation that hangs over the play recalls the complaints of anti-enclosure agitators, who feared that they might "pine ... to death for want of $\mathrm{y}^{\mathrm{t}} \mathrm{w}^{\text {ch }}$ these deuouring encroachers do serue theyr fatt hogges and sheep withal." ${ }^{28}$ Even Shakespeare's placement of hunters and shepherds in the same forest-space reminds one of the two groups' incompatibility. In 1528, for instance, High Peak Forest was reportedly overrun with "no fewer than five herds of cattle (amounting to 903 animals) . . . as well as over 4,000 sheep and 320 horses," so "it was no wonder that the deer stock had gone into serious decline." 29

17 In this context, Duke Senior's hunting of venison inevitably raises questions of entitlement and ownership. The very act of taking deer in the Forest of Arden, where the new Duke Frederick has granted Senior and his followers "good leave to wander" (1.1.103-4), elides those who hunt by aristocratic right with those who poach game in defiance of the law. In this respect it becomes hard to determine the actual legal status of the hunting in question. When Senior was duke, he would have held unchallenged right to hunt in his own forest, but does Frederick's "good leave to wander" extend to the taking of game as well? While this remains unclear, Shakespeare's treatment of Duke Senior unquestionably recalls the scofflaw insurgency of "the old Robin Hood of England" (1.1.116), whose exploits were celebrated in the late 1500s both onstage and off. Thus in the popular Gest of Robyn Hode (c. 1450), reprinted repeatedly during the sixteenth century, King Edward responds to poaching by confiscating the lands of Robin Hood's friend Sir Richard at the Lee and seeking Robin Hood himself in the greenwood, where the outlaw entertains the disguised king by stealing and then 
serving him the king's own deer. ${ }^{30}$ In effect, Shakespeare's play works a variation on this motif, as Duke Senior, deprived of his own lands, poaches what used to be his own game and serves it to himself. But in the fifteenth-century ballad, Robin Hood is a "gode yeman"; $; 1$ in As You Like It, Duke Senior is a titled aristocrat with a following of landed gentlemen. In this regard Shakespeare follows Anthony Munday's Robin Hood plays of the 1590s, The Downfall of Robert, Earl of Huntingdon and The Death of Robert, Earl of Huntingdon (1598), which may have provided commercial stimulus for Shakespeare's comedy. Munday's plays are best known today for initiating the "gentrification" of the Robin Hood tale, transforming its protagonist into a lord and assimilating it to the ethos of pastoral romance..$^{32}$ In the event, this is also much what Shakespeare does.

In recasting Robin Hood as a peer, however, Munday and Shakespeare detach the folk hero from his earlier political and social affiliations, with the result that he no longer embodies a specifically popular resistance against the impositions of corrupt and selfserving magistrates. Yeoman virtues aside, Munday's Robin Hood loses his estate through a signature aristocratic vice: the bankruptcy of those "that reuell, wast and spende, and take no care." ${ }^{33}$ The financial embarrassment of the peerage, of course, is a central bugbear of Lawrence Stone's "crisis of the aristocracy," ${ }_{34}$ and under its influence Munday's Robin Hood plays steer away from issues of popular rebellion, instead foregrounding competition between rival members of the ruling elite. With its focus on aristocratic sibling rivalry, As You Like It follows suit. As a result, these plays all engage in a kind of ideological co-optation, assimilating the language of social resistance to the mythology of titled privilege. When Munday's Earl of Huntingdon enters the greenwood he forbids his followers to address him "By name of Earle, Lord, Baron, Knight or Squire:/ But simply by the name of Robin Hoode" ${ }^{35}$-a command that transforms the egalitarianism of outlaws into an effect of sovereign power. For his part, Duke Senior retains his rank more clearly. He may refer to his followers as "co-mates and brothers in exile" (2.1.1), but he hangs onto his precedence among them as well as his honorifics, figuring as "your Grace" (2.1.18), "my lord" (2.1.25), and "my lord" again (2.1.65) within his first seventy lines onstage. In this rhetorical environment, Duke Senior's fraternalism, like his philosophical acceptance of the rigors of outdoor life, paradoxically enhances his nobility.

When it comes to As You Like It's criticism of hunting, much the same thing can be said. The play assigns this criticism to two characters: briefly (for five lines) to Duke Senior, and at greater length to Jaques. In the former case, the sentiments are fleeting and anodyne, advocating no action and producing no results with respect to the treatment of animals. To the contrary, Duke Senior's reservations about hunting seem designed for two purposes: to present the duke as ethically scrupulous and tender-hearted-i.e. noble-natured-and, somewhat contradictorily, to introduce his mockery of Jaques' thoughts on the same subject. "It irks me," Duke Senior complains, that the local deer, "Being native burghers of this desert city,/ Should in their own confines .../ Have their round haunches gor'd" (2.1.22-5) -an expression of sympathy that mutates rather too easily into a kind of self-pity. This is the point of Jaques' reported objection "that in that kind ... you do more usurp/ Than doth your brother that hath banish'd you" (2.1.27-8); Duke Senior's concern for animal welfare, like the play's critique of his brother's usurpation, rests on a notion of natural entitlement disrupted unjustly by force and brutality. To this extent, Duke Senior's pursuit of "venison" (2.1.21) seems to anticipate Duke Frederick's abortive pursuit of his elder brother into "the skirts of this wild wood" (5.4.159). And given the relentless optimism of Shakespeare's comedy, it 
only makes sense that both pursuits should end improbably well: just as Duke Frederick's last-minute religious conversion spares his elder brother's life, the only food actually mentioned on Duke Senior's sylvan table is "fruit" (2.7.99).

To this point the objections to hunting in As You Like It function mainly in the utopian register, to mark Duke Senior as compassionate of heart and intrinsically noblespirited, to associate his authority with the natural entitlement of woodland beasts, and to connect him as well with the "long humanist tradition, its roots in classical antiquity, that deplored hunting not only as a waste of time, but an activity harmfully inuring men to bloodshed and cruelty." ${ }^{36}$ With Jaques' remarks, however, we move into the territory of satire, and its attendant social criticism cuts two ways: first toward Duke Senior, when Jaques accuses him of usurping the forest as Frederick has done his dukedom, and then back toward Jaques himself, as Duke Senior and his followers mock his theriophily. In this context, Duke Senior's own moral scruples provide a preemptive defense against Jaques' accusations of despotism. Laurie Shannon has argued that early modern definitions of tyranny rest upon "two elements": "a cruel violence that violates [the tyrant's] fiduciary charge," and "usurp[ation of] another's place." ${ }^{37}$ In the event, Jaques' complaint against Duke Senior draws on both these elements, accusing him of usurpation directly (2.1.27) and then spinning the violence of hunting into "a thousand similes" (2.1.45) of extravagant lament. In the process, Jaques offers both sentimental identification with the suffering of hunted beasts and an indignant denunciation of the abuse of power. What he doesn't seem to offer, from the standpoint of the characters around him, is any critique of human behavior cogent enough to demand a serious response.

21 Quite the contrary, in fact: far from impugning Duke Senior's humanity, Jaques' remarks seem to compromise his own. That, at least, seems to be the point of Duke Senior's observation that "I think he be transform'd into a beast,/ For I can nowhere find him like a man" (2.7.1-2). Somewhere in his sympathetic identification with the forest and its "native burghers" (2.1.23), Jaques has compromised his own status as a reasoning (hence human) being, in the process disqualifying himself as an exemplar of virtuous behavior. Hence the connection between his theriophily and his muchcensured "melancholy" (2.1.26): both mark a morbid withdrawal from society, an arrogant setting-apart of the self. This misanthropy may be easily recast as Jaques' own all-too-human hypocrisy: "Most mischievous foul sin, in chiding sin:/ For thou thyself hast been a libertine,/ As sensual as the brutish sting itself" (2.7.64-6). The point here does not seem to be to raise specific accusations, but rather to involve Jaques in the general condition of the very beings he seeks to condemn. Given his own compromised nature (one might call it original sin), Jaques lacks any privileged space from which to "cleanse the foul body of th'infected world" (2.7.60). His reformation has always already failed.

22 That being the case, it makes sense that Jaques, the erstwhile critic of animal cruelty, should also appear in his play leading a triumphal procession prominently featuring the "leather skin and horns" (4.2.13) of a recently-killed deer, a procession in which the hunter of the deer in question is presented to Duke Senior "like a Roman conqueror" (4.2.3-4). Richard Wilson has identified this gathering as a skimmington or charivari: "a caterwauling ritual of the Cheese country" designed to shame neighbors who have violated sexual norms or to humiliate landowners who are perceived as unfairly prosperous. ${ }^{38}$ In this respect the scene again illustrates Jaques' satirical function, and- 
as with Jaques' earlier criticism of hunting-the target is once more Duke Senior. But it is satire divested of any serious remedial function, airing no grievances and making no demands. Instead, the procession subsides into a rueful mock-encomium to the human condition, as represented metonymically by the cuckold's horns:

Take thou no scorn to wear the horn,

It was a crest ere thou wast born;

Thy father's father wore it,

And thy father bore it.

The horn, the horn, the lusty horn

Is not a thing to laugh to scorn.

(4.2.13-16)

(1)

through her skill as "a magician" (5.2.71). As the skimmington points toward As You Like It's roots in satire, the masque embodies its debt to the utopian world of courtly entertainments, while gesturing simultaneously toward the miraculous spiritual transformation whereby Duke Frederick is "converted" to a "religious life" (5.4.161, 181). Together, the two episodes speak to the ideal of marital fidelity, on the one hand, and its all-too-frequent lapse into betrayal, on the other. Thus, as Shakespeare's comedy ends, the satiric and utopian modes coincide. Both Jaques and Rosalind note the likelihood that not all of the play's married couples will thrive in wedlock, and Jaques concludes the action by abandoning the celebration, throwing "into neglect the pompous court" (5.4.182), and resorting instead to the newly-converted Frederick and his spiritual counselor. "Out of these convertites," Jaques explains, "There is much matter to be heard and learn'd" (5.4.184-5), his language echoing that of Duke Senior himself when, earlier, he declares Jaques himself "full of matter" (2.1.68). But whatever the "matter" in question may be, whether satirical or spiritual, philosophical or melancholic, it remains foreign to the "dancing measures" with which the play itself concludes (5.4.193). Those measures signal the triumph of the utopian over the satirical, optimistic faith over inconvenient facts, and As You Like It celebrates such triumph with none but the most cursory, self-serving regard for the lives, both human and nonhuman, expended in its pursuit.

25 Robert Watson has argued that while "the deer-hunt scenes [in As You Like It] offer some emotional aid and comfort to the animal rights movement, the play as a whole undercuts that endorsement by demonstrating that such pervasive anthropomorphizing sentiments may invade and constrain the animal world more insidiously than sporadic open warfare. ${ }^{39}$ As a harmonizing observation, we might note that the encomiastic and satirical modes in As You Like It conjointly demarcate the space of the impossible-the golden world, the reformation of vice-and that in doing so they concede the present moment as always already lost. We seek out Arden only to rediscover Horace's adage that those who fly across the ocean change the heavens, not their hearts. And it turns out our hearts are not especially friendly to other animals-or to the world around us.

26 Finally, then, the happy ending of As You Like It points us toward one more momentan ending-beyond-ending, as it were-when, all passions spent and disposed in orderly fashion, the play's blocking characters abandon their worldly interests and choose 
instead a life of withdrawn spiritual contemplation. On one level, this staged retirement enacts the "mockery of what is unnatural" that C. L. Barber described as central to the flyting and abuse of festive comedy. ${ }^{40}$ On another level, however, the retreat into sylvan indistinction can be seen as a withdrawal into reality itself, away from the comforting fantasies that comprise the stock-in-trade of

Shakespeare's work. Jaques, Frederick, and the hermit whose company they seek all exist, to one degree or another, on the fringes of their play's consciousness, the last of the three never appearing onstage, the second invisible after the start of Act 3, the first permitted onstage precisely to foreground his incompatibility with and ultimate removal from society. Taken together, they move toward a natural realm beyond the compass of the play's imaginings, an unthinkable "unground" or "negation or Divine Abyss" like that explored in Eugene Thacker's Horror of Philosophy: neither present nor absent, plural nor singular, subject nor object, a site of necessary and perfect indifference to the human. ${ }^{41}$

Here we might locate the space of what Robert Watson calls "true natural perception" in Shakespeare's play, and it is the space of flight and displacement. ${ }^{42}$ This seems appropriate to the play's exilic setting, with its conflation of liberty and banishment, and it accords equally well with Shakespeare's depiction of flight to the greenwood as a kind of spiritual exercise, replete with sermons in stones and books in running brooks. With a more-than-coincidental symmetry, Thacker's language for the world-in-itself - "unground," "Divine Abyss"-derives from the theology of Jakob Böhme. Likewise, Thacker poses the problem of our relations with the non-human universe in mystical terms borrowed from Georges Bataille:

For Bataille, our fundamental discontinuity as human beings in the world has, at its greatest or most extreme limit, an overflowing negation that posits, in a contradictory way, the continuity that is also our own, non-human limit. To exist as the world, we must cease existing in the world. ${ }^{43}$

By the end of As You Like It, this is just what Jaques and Frederick have done, disappearing from the social world of the play so as to become, in the process, true "native burghers" of the Forest of Arden. It is a trick already performed by Orlando's servant Adam, too, whose premature but most convenient disappearance becomes, within the framework of Shakespeare's comedy, the functional equivalent of death. And we might finally speculate that Shakespeare stages much the same disappearance, and much the same relation to the natural world, under the rubric of tragedy, in the heath-scenes from King Lear.

\section{NOTES}

1. ${ }^{1}$ See for instance Catherine Bates, "George Turberville and the Painful Art of Falconry," English Literary Renaissance 41.3 (Autumn, 2011), p. 403-28; Bates, Masculinity and the Hunt; Wyatt to Spenser 
(Oxford: Oxford UP, 2013), p. 111-44; Bergman p. 53-73; Berry p. 33-34, p. 162-3, and passim; Matt Cartmill, A View to a Death in the Morning: Hunting and Nature Through History (Cambridge, USA: Harvard UP, 1993), p. 76-91; Nicole Mennell, “'Compassionate Consumption'? George Gascoigne's 'The Noble Art of Venerie or Hunting' and the Voice of the Dish," Renaissance Hub (April 10, 2017): http://www.renaissancehub.net/single-post/2017/04/10/Compassionate-Consumption-GeorgeGascoignes-The-Noble-Art-of-Venerie-or-Hunting-and-the-Voice-of-the-Dish; Stephen Hamrick, "'Set in portraiture': George Gascoigne, Queen Elizabeth, and Adapting the Royal Image," Early Modern Literary Studies 11.1 (May, 2005): http://purl.oclc.org/emls/11-1/hamrgasc.htm. For a related discussion of Gascoigne that does not focus directly on The Noble Arte, see Jonathan Crewe, Trials of Authorship: Anterior Forms and Poetic Reconstruction from Wyatt to Shakespeare (Berkeley: U of California P, 1990), p. 118-39.

2. Bergman, op. cit., p. 71; Bates, “Turberville”, p. 405.

3. For the humanist opposition to hunting, see e.g. Desiderius Erasmus, The Praise of Folly, in The Praise of Folly and Other Writings, ed. and trans. Robert M. Adams (New York: Norton, 1989), 40; Sir Thomas More, Utopia, trans. Paul Turner (London: Penguin, 2003), p. 75-6.

4. Mennell, op. cit.

5. Guillaume Bouchet, "Complainte du cerf, a Monsieur du Fouilloux," in Jacques du Fouilloux, La venerie du Jacques du Fouilloux (Poitiers, 1561), p. 291-4.

6. George Gascoigne, The Noble Art of Venerie or Hunting (London, 1611), p. 198.

7. Gascoigne 137-9. For the separate traditions tracing the formation of bezoar-stones to tears and stomach secretions respectively, see Edward Topsell, The historie of foure-footed beastes (London, 1607), 127; Robert Burton, The Anatomy of Melancholy, ed. Holbrook Jackson, 3 vols. in 1 (New York: Vintage, 1977), 2: p. 219.

8. Gascoigne, op. cit., p. 137.

9. Bates, Masculinity, p. 141.

10. Bouchet, op. cit., p. 291, p. 293

11. Gascoigne, op. cit., p. 198.

12. Hugh MacLean, "Complaints," The Spenser Encyclopedia, ed. A. C. Hamilton (Toronto: U of Toronto P, 1990), p. 177-81; p. 177.

13. MacLean, op. cit., p. 178.

14. Bates, Masculinity 115.

15. Berry, op. cit., p. 77.

16. See du Fouilloux, op. cit., p. 272-285.

17. Gascoigne, op. cit., p. 140.

18. Du Fouilloux op. cit., p. 109; Gascoigne op. cit., p. 92-3.

19. See Gascoigne sig. $3 \mathrm{v}-4 \mathrm{r}$ (unpaginated) for the text of this poem.

20. Bergman op. cit., p. 70; Mennell, op. cit.

21. OED "Gentle," adj. 6 e.

22. Bates, Masculinity p. 139. See also Crewe, op. cit., p. 133.

23. Berry, op. cit., p. 28.

24. Juliet Dusinberre, "Introduction," in William Shakespeare, As You Like It, ed. Juliet Dusinberre (London: Arden, 2006), p. 95.

25. For the War of the Theaters, see James Bednarz, Shakespeare and the Poets' War (New York: Columbia UP, 2001), esp. p. 83-105.

26. Berry, op. cit., p. 162, 1p. 60-63.

27. Richard Wilson, "'Like the old Robin Hood': As You Like It and the Enclosure Riots," Shakespeare Quarterly 43.1 (Spring, 1992): p. 2.

28. "The Diggers of Warwickshire to all other Diggers," B.M. Ms. Harl. 787, art. II, in James Orchard Halliwell, ed., The Marriage of Wit and Wisdom, an Ancient Interlude, to which are added Illustrations of Shakespeare and the Early English Drama (London: Shakespeare Society, 1846), p. 141. 
29. J. Charles Fox, The Royal Forests of England (London, 1905), 171-2, qtd. in Emma Griffin, Blood Sport: Hunting in Britain since 1066 (New Haven: Yale UP, 2007), p.70.

30. See A Gest of Robin Hode, Seventh Fytte, in Robin Hood and Other Outlaw Tales, ed. Stephen Knight and Thomas Ohlgren (Kalamazoo: TEAMS Middle English Texts, 2000), p. 135-43, 1. 1413-1668.

31. A Gest of Robin Hode, First Fytte, p. 90, 1. 3.

32. See Meredith Skura, “Anthony Munday's 'Gentrification' of Robin Hood," English Literary Renaissance 33.2 (Spring, 2003): 155-80

33. Anthony Munday, The Downfall of Robert, Earl of Huntingdon (n.p.: Tudor Facsimile Texts, 1913), D4r.

34. See Lawrence Stone, The Crisis of the Aristocracy 1558-1641 (Oxford: Oxford UP, 1987), p. 233-67.

35. Munday F1r. See also D4v, as well as Anthony Munday, The Death of Robert, Earl of Huntingdon (n.p.: Tudor Facsimile Texts, 1913), B3v.

36. Anne Barton, The Shakespearean Forest (Cambridge, UK: Cambridge UP, 2017), p. 13-14.

37. Laurie Shannon, The Accommodated Animal: Cosmopolity in Shakespearean Locales (Chicago: U of Chicago P, 2013), p. 78.

38. Wilson, op. cit., p. 13.

39. Robert Watson, Back to Nature: The Green and the Real in the Late Renaissance (Philadelphia: $U$ of Pennsylvania P, 2006), p. 82.

40. C. L. Barber, Shakespeare's Festive Comedy: A Study of Dramatic From and its Relation to Social Custom (Princeton: Princeton UP, 1959), p. 8.

41. Eugene Thacker, In the Dust of This Planet (Horror of Philosophy, Volume 1) (Winchester, UK: Zero Books, 2010), p. 141.

42. Watson, op. cit., p. 100.

43. Thacker, op. cit., p. 149.

\section{ABSTRACTS}

This paper revisits the relationship between George Gascoigne's Noble Arte of Venerie (1575) and Shakespeare's As You Like It (1598). In the process it argues against the currently popular tendency to read these works as augurs of the modern animal-rights sensibility, preferring to understand them instead as expressions of an older and less accommodating sense of interspecies relations. This older view, consistent with the doctrine of original sin, understands fallen humanity as given by nature to predation and strife, constitutionally unsuited to the practice of peace. Thus Duke Senior's anti-hunting sentiments in As You Like It invoke an ideal of paradisal harmony like that staged in the courtly entertainments composed by Gascoigne and others for Queen Elizabeth-these being, it has been argued, a major source for the language of Shakespeare's play. By contrast, Jaques assimilates the same anti-hunting sentiments to the register of satire, marking in the process their distance from reality. Within As You Like It, these responses to the real-the utopian and the satirical, the idealizing and the accusatory-find expression in twin concluding spectacles: Rosalind's wedding-masque and Jaques' charivariprocession, the two uniting in a kind of discordia concors. In their contrasting harmony, utopia and satire alike reject the possibility of ideal behavior in the here and now; likewise, Gascoigne's Noble Arte marginalizes its anti-hunting sentiments by casting them in the form of verse exercises, liminal and cosmetic, rhetorical rather than actual. By together placing inter-species 
sympathy in the realm of the unattainable and prelapsarian, Gascoigne and Shakespeare commit themselves to a vision of the fallen world as both ethically and ecologically unredeemable. Perhaps not by coincidence, this world anticipates the environment in which later Shakespearean plays like King Lear and Macbeth unfold.

Le présent article envisage à nouveaux frais les liens entre le traité sur la chasse de George Gascoigne, The Noble Arte of Venerie (1575) et Comme il vous plaira (1598) de Shakespeare. Contrairement à l'idée selon laquelle ces œuvres préfigurent la sensibilité moderne aux droits des animaux, il s'agit de les comprendre à l'aune de relation inter-espèces plus anciennes et moins souples. Cette perspective plus datée, conformément à la doctrine du péché originel, voit l'humanité déchue naturellement encline à la prédation et au conflit et inapte par constitution aux pratiques pacifiques. Aussi les sentiments anti-cynégétiques attribués au Duc aîné dans Comme il vous plaira invoquent-ils un idéal d'harmonie édénique semblable aux mises en scène des divertissements royaux composés par Gascoigne et d'autres pour la reine Élisabeth (dont il a été démontré qu'ils représentaient une source majeure de la langue de la comédie shakespearienne). À l'inverse, Jaques assimile les mêmes sentiments anti-cynégétiques au registre de la satire, marquant ainsi leur éloignement de la réalité. Dans la pièce, l'ensemble des réponses opposées au réel (l'utopie et la satire, l'idéalisation et l'accusation) trouvent à s'exprimer dans le double spectacle final, le masque pour le mariage de Rosalinde et la procession charivaresque de Jaques, les deux étant réunis en une sorte de discordia concors. Dans cette harmonie de contrastes, l'utopie comme la satire rejettent la possibilité d'un comportement idéal dans l'ici et maintenant. Le traité de Gascoigne, de la même façon, repousse à la marge ses sentiments anti-cynégétiques en les présentant sous forme d'exercices versifiés, liminaires et cosmétiques, soit plutôt rhétoriques que réels. Reléguant la sympathie inter-espèces au domaine de l'inaccessible et du prélapsaire, Gascoigne et Shakespeare tranchent dans le sens d'une vision du monde d'après la chute qui serait éthiquement et écologiquement irréparable. Peut-être ne faut-il pas voir comme une coïncidence le fait que ce monde préfigure l'environnement qui caractérise des pièces plus tardives telles que Le Roi Lear ou Macbeth.

\section{INDEX}

Mots-clés: Shakespeare William, chasse, Gascoigne George, pastoral, conservationnisme, thériophilie, droits des animaux, Fouilloux Jacques du

Keywords: Shakespeare William, Hunting, Gascoigne George, pastoral, conservationism, theriophily, animal rights, Fouilloux Jacques du

\section{AUTHOR}

\section{BRUCE BOEHRER}

Bruce Boehrer is Bertram H. Davis Professor of early modern English literature at Florida State University. His most recent books are Environmental Degradation in Jacobean Drama (Cambridge, 2013) and Animals and Animality in Literature (co-edited with Molly Hand and Brian Massumi; Cambridge, 2018). 